\title{
Javanese Language Dialect in Java-Sunda Border Area (Dialect Study of Geography in Brebes District)
}

\author{
Ghulam Arif Rizal ${ }^{1}$, Ida Zulaeha ${ }^{2}$, Imam Baehaqie ${ }^{3}$ \\ \{1 rizalfrance@gmail.com, ${ }^{2}$ idazulaeha@mail.unnes.ac.id, ${ }^{3}$ imambaehaqie@mail.unnes.ac.id $\}$ \\ Graduate School, Universitas Negeri Semarang, Indonesia.
}

\begin{abstract}
Javanese and Sundanese languages on the border of Central and West Java are unique, especially in Brebes district. Most of the residents of Brebes Regency on the border cannot use Javanese but are able to win the Sundanese. The purpose of this study was to analyze Javanese and Sundanese in Brebes in the Javanese-Sundanese border region. This research is a descriptive qualitative type. The method used is the technique refer to and note. The results showed that the Javanese dialect in the area had lexicon distribution in Sirampog, Paguyangan, Bumiayu, and Tonjong. While the distribution of Sundanese languages is in the district of Salem. An important finding of this study, namely the distribution of lexicons in Javanese or Sundanese languages, is available in Bantarkawung sub-district.
\end{abstract}

Keywords: dialect, Javanese, Sundanese, Brebes.

\section{Introduction}

The Indonesian nation has many ethnic groups, so the language used is also different. Contact between one language and another language must reap influence, both on a strong scale and on a weak scale. Based on this, the linguists conducted research on language mapping in several regions. These differences include speech (parler), subdialect (sous dialecte), dialect (dialecte), then in the highest collection, namely language differences (langue). One of the ethnic groups in Indonesia is the Javanese, who have Javanese. Javanese is the language used by the entire population of Java, especially in the province of Central Java and as a mother tongue. This language is used as a mother tongue by Javanese, especially those who live in the provinces of Central Java, Yogyakarta (DIY), and East Java, [1]. Brebes Regency is one of the districts in the west of Central Java Province. The focus of the study in this study is the geographic dialect found in the Central Java-West Java border region. The object of the research is Javanese which is spoken by six sub-districts in South Brebes, one of which is the border between Central Java and West Java. The area is directly adjacent to the Cirebon district and Kuningan district as a Sundanese language speaking community.

The Javanese dialect in Brebes is a geographical variation of Javanese. Dialectic geography is a branch of linguistics that specializes in studying language variations based on local differences from all aspects [2]. The geographical dialect in this study focuses on how the local dialect is spread. The local dialect includes two languages, namely Sundanese and Javanese as its parent.

Differences in dialect in Javanese are peculiarities that are lingually unique. These differences can be found in different sub-districts in one district. One dialect is different from 
the other dialects, each of which has a lingual characteristic. This particularity is what distinguishes these dialects, [3]. The peculiarities of the Brebes dialect of Javanese language have not previously been studied. The need to conduct this research is as a form of literature research on the distinctiveness of the Javanese language in the Brebes dialect, and as a mapping of the Javanese dialect of the Brebes dialect in the Javanese-Sundanese border area, namely between the Brebes regencies of Central Java and the Kuningan District of West Java. The distinctiveness of the Brebes dialect of Javanese language has a distinctive sound as in the research. [4] The judge in the study of phonology of his research shows that in the Javanese Language the Brebes dialect has several sound variation processes, including assimilation, impingement, and addition. This study took Javanese language objects that were spoken by the Brebes people on the North coast. The research that has not been done is to make the object of study in the Brebes district, namely six sub-districts consisting of Sirampog, Tonjong, Bumiayu, Paguyangan, Bantarkawung and Salem sub-districts.

This study analyzes the local dialect language, namely the Javanese dialect of Brebes, which at a glance is similar to the Banyumas dialect, the Tegal dialect. This similarity does not explicitly conclude that the dialect at Brebes is a sub-dialect of the Tegal dialect and the Banyumas dialect. This relates to determining dialect criteria and sub-areas. Determination of appropriate, accurate, and comprehensive criteria to be able to distinguish between the figure of a language and the figure of a dialect is the most difficult thing in the field of dialectology, even though this is very basic because both direct and indirect, the activities carried out by dialectologists have an impact on grouping and counting number of languages in the world [5].

This research is specifically included in the study of geographic dialects. Dialectic geography is a study that studies language variations based on local differences in a language area [6]. Regarding the regional dialect of geography or dialect, means the geographical dialect, regional dialect as a dialect whose characteristics are limited by place [7]. It can be concluded that the geographic dialect is a study that describes language variations in a number of regions, classifies the same variations and compares differences in a particular region, both synchronously and diachronically.

This research supports identical research before, one of them in a study conducted entitled "Lampung Language dialect geography in the southern part of Sumatra." In his study it was concluded that four isolek groups namely dialect, sub-dialect, speech differences, and none difference; this grouping is supported by the qualitative fact of isogloss. Isoglos is very dominant in dialect groups and sub-districts, [8]. The novelty in this research is dialectology research, which focuses on geographic dialects in the Java-Sunda border region. Previous research on dialectology, both the social dialect and the geographic dialect in Brebes or other regions, still had little research on the two-language border region.

The purpose of this study is to describe the distribution of the use of Javanese and Sundanese in Brebes in the border region. The data in this study are in the form of Javanese lexicons, the distribution of lexicons is depicted in a geographical map based on the high and low influence of the Sundanese language. Research data in the form of primary data and secondary data. Primary data in the form of lexicons of Javanese and Sundanese are spoken from informants at the point of observation. Sekundar data of this study is in the form of sound recordings from informants. Other secondary data comes from other studies published in journals related to Javanese and Sundanese. Secondary data are supporting data such as recordings, journals, and related research before, [9] Chamalah.

Based on dialectology theory, geographic dialect research will take data with various techniques. The technique in this study uses note taking techniques and records. [10] Mahsun techniques are proficient at the same time, note-taking techniques, and recording techniques are 
ideal because researchers can directly know the geographical conditions of the observation area. Likewise with the note-taking technique, the researcher can immediately record the realization of certain phonemes by directly paying attention to the informant's speech organ that produces certain sounds. Data in the form of lexicons of Javanese and Sundanese languages from informants who use local languages, both from Javanese and those who use Sundanese they get directly from parents as mother tongue. Fishing techniques, see, and note are used to extract information from the informants, [11] Suyata. Fishing techniques, see the need and note are done as an explanation of each local dialect lexicon to convince researchers for the validity of the data.

\section{Method}

This research method uses descriptive qualitative. This study uses the technique of referring, noting, and recording. Primary data in this study came from the Brebes district community which consisted of six sub-districts. The technique in collecting research data comes from informants at various observation points. Informants who fulfill the following requirements inform local language lexicons of various categories of prepared gloss (nature, body parts, numbers, etc.). Furthermore, the recording technique is used to support the implementation of the note-taking technique, which is to re-check the data that has been recorded with the recordings produced with the record tool.

\section{Results and Discussion}

The lexicon distribution of the local dialect in six regions covering Sirampog sub-district, Paguyangan sub-district, Bumiayu sub-district, Tonjong sub-district, Bantarkawung sub-district and Salem sub-district is described as follows:

Sirampog

The lexicon distribution observed at the observation point indicated that the Javanese dialect of the local dialect was still a Javanese lexicon. The Lexicon that is typical of the right area has the difference from the standard Javanese lexicon, Yogya-Solo. The kiwa lexicon is a form of "left" in Indonesian, and kiwo in Javanese standard.

The difference in lexicon at the observation point:

a. Unlike the observation points in other districts. dipanggil: digero sampai: anjog. beri: nein. (Javanese).

b. different from the standard Javanese language of Yogya-Solo. bara: wangwa, laut: segara, jalan lebar: dalan amba. (Javanese).

The unique characteristic of the local dialect is the difference in the lexicon in referring to the pegangan in Bahasa. At the observation point in the village of Manggis it becomes a cekelan while in the village Dawuhan gocelan. The geographical difference in the two villages is in the highlands. The location of Dawuhan village in the east is higher than the western one in Manggis, the land is lower.

It can be concluded that the distribution of the lexicon at the observation point in the Sirampog sub-district used is a lexicon of the Javanese language.

Tonjong 
The lexicon distribution at the observation point in Tonjong sub-district has similarities with the other sub-districts in South Brebes. The difference is found in the intonation which tends to be higher in the question sentence.

The difference in lexicon at the observation point:

a. Unlike the observation points in other districts. dipanggil: diundang, sampai: teka, beri: wei. (Javanese).

b. different from the standard Javanese language of Yogya-Solo.

rumah: umah, pagar: rajeg. (Lexicon in Javanese).

It can be concluded that the distribution of the lexicon at the observation point in the Tonjong sub-district the language used is a lexicon of Javanese.

Bumiayu

The Javanese lexicon at the observation point in Bumiayu sub-district has a complex distribution. The influence and interference of dialects from other regions affect the lexicon in the pengamantan in the Bumiayu sub-district. Geographically, Bumiayu is the center of the city in South Brebes so that residents of all sub-districts in South Brebes visit Bumiayu. These influences have an impact on the language used.

The difference in lexicon at the observation point:

a. Unlike the observation points in other districts.

diundang: diceluk, kukur: nggaruk, beri: ngai (Javanese).

b. Unlike the standard Javanese language of Yogya-Solo.

sedikit: secuil. (Javanese).

It can be concluded that the distribution of the lexicon at the observation point in the Bumiayu sub-district the language used is the lexicon of the Javanese language.

Paguyangan

Javanese spoken in Paguyangan is geographically close to the Banyumasan dialect. Directly adjacent to Pekuncen sub-district, Banyumas district. The scattered lexicon is also influenced by the Banyumas dialect, for example in the emphasis on the question sentence which ends with the lexicon, mbok?.

The difference in lexicon at the observation point:

a. Unlike the observation points in other districts. jatuh: tiba, sampai: tekan. beri: nei. (Javanese).

b. Unlike the standard Javanese language of Yogya-Solo. nyamuk: lemud, tangga: undagundagan. (Javanese).

It can be concluded that the distribution of the lexicon at the observation point in the Paguyangan sub-district the language used is the lexicon of the Javanese language.

Bantarkawung

The lexicon distribution at the safety point in Bantarkawung sub-district is divided into two languages. Some residents use Javanese and others use Sundanese.

The difference in lexicon at the observation point:

a. Unlike the observation points in other districts.

memikul: manggul. (Sundanese).

b. different from the standard Javanese language of Yogya-Solo.

mendahului: ndisiti. (Javanese).

It can be concluded that the distribution of lexicons at the observation points in Bantarkawung sub-district the language used is the lexicon of two languages, namely Javanese and Sundanese.

Salem 
Informants at the observation point in the Salem sub-district used Sundanese as their daily language, the Javanese language which was controlled by limited informants. The existing Sundanese lexicon is not entirely the same as the Baku Sundanese lexicon, as in the Javanese language at this research observation point it is not the same as the Yogya-Solo standard Javanese language.

The difference in lexicon at the observation point: a. Unlike the observation points in other districts. enam: genep. (Sundanese).

b. different from the standard Javanese language of Yogya-Solo. mendahului: ndingini, teman: batir. (Javanese).

It can be concluded that the distribution of the lexicon at the observation point in the Salem district of the language used is the lexicon of the Javanese language.

Based on the results of data analysis, it can be mapped the distribution of lexicons by mapping as follows.

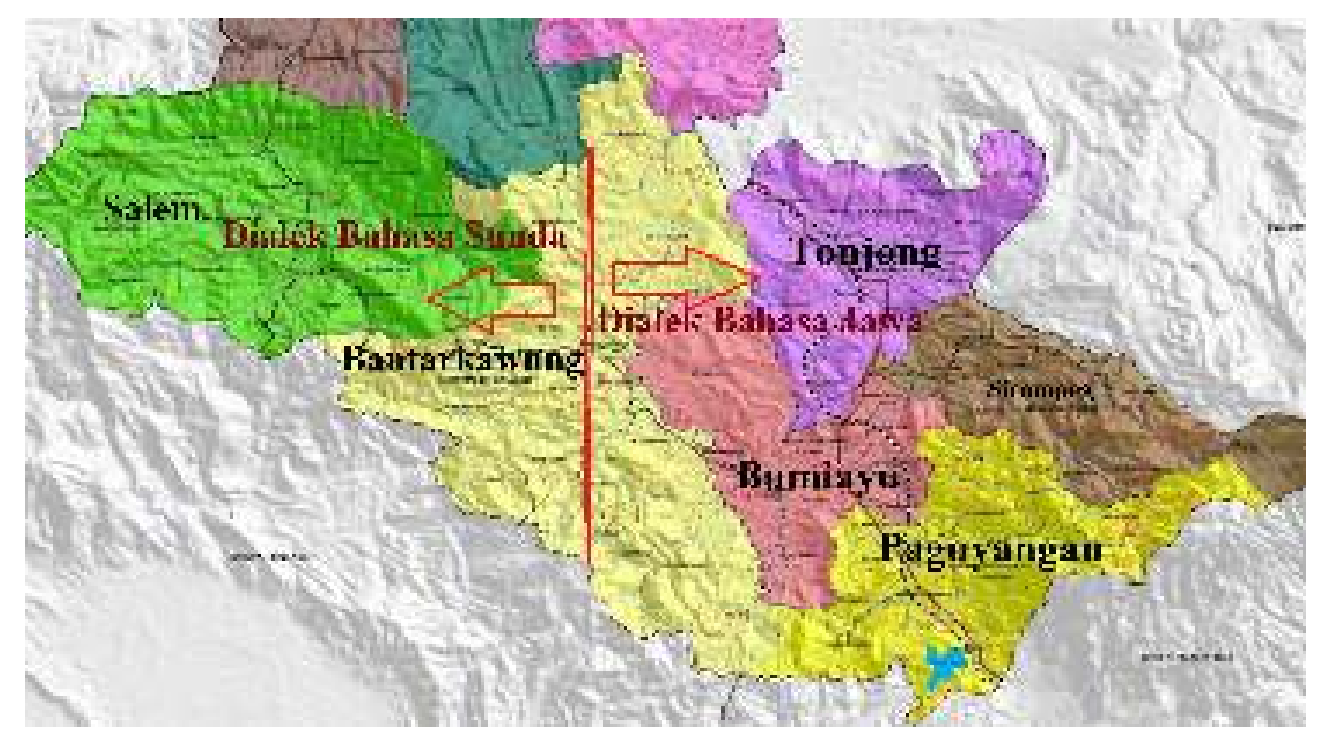

Distribution of Javanese lexicons and Sundanese lexicons in South Brebes.

Figure 1. Mapping of the Javanese and Sundanese dialects in South Brebes.

\section{Conclusion}

The results of the analysis, it can be concluded that the South Brebes Javanese language dialect in the border region has a distribution of lexicons which can be described as follows: Brebes Javanese is spread in Sirampog sub-district, Paguyangan sub-district, Bumiayu subdistrict, and Tonjong sub-district. Whereas in the Salem sub-district, the distribution is Sundanese-speaking speakers. Subsequent results from the Bantarkawung sub-district, the language used in part using the Brebes dialect Javanese language, and some using the local dialect Sundanese language. An important finding based on the results of the analysis is the Bantarkawung sub-district as the limit of the use of Javanese language. The population in this 
region tends to be able to master the Javanese language, while the use of everyday language is Sundanese. The conclusions that can be taken are the distribution of Javanese lexicons in South Brebes not spoken in two sub-districts, namely Bantarkawung and Salem. 


\section{References}

[1] Chamalah, 2018

[2] Kurniati, E \& Mardikantoro, H. Pola Variasi Bahasa Jawa (Kajian Sosiodialektologi pada Masyarakat Tutur di Jawa Tengah. (2010). Humaniora, 22(3), 273-284. https://doi.org/10.22146/jh.v22i3.1001.

[3] Ida Zulaeha. (2010). Dialektologi Dialek Geografi dan Dialek Sosial. Yogyakarta: Graha Ilmu.

[4] Heryadi, T. (n.d.). Nama Jenis Makanan Dan Minuman Tradisional Di Kecamatan Majalaya , Kabupaten Bandung Dialect Variants for Geographic Names of Traditional Food and Beverages in Majalaya District ,. 135-146.

[5] Hakim, M. A. (n.d.). Bahasa Jawa Dialek Brebes; Sebuah Telaah Fonologi Generatif.Jurnal Lingua Idea. Vol 7, no. (2), 30-4. (2017).

[6] Lauder, M. R.M.T. Sekilas Mengenai Pemetaan Bahasa. Jakarta: Akbar Media Eka Sarana. (2007)

[7] Keraf, G. Tata Bahasa Indonesia. Nusa indah, Jakarta. (1984).

[8] Kridalaksana, H. Pembentukan kata dalam Bahasa Indonesia, Jakarta: PT. Gramedia Pustaka Utama. (2007).

[9] Sardiman. Geografi Dialek Bahasa Lampung Di Wilayah Sumatera Bagian Selatan. Tesis. Universitas Gadjah Mada. (2006).

[10]Chamalah, E. Local Litterature in Coastal Pesantrens as an Alternative on Literary Reading Subject for Students of PBSI Unissula. Advances in Social Sience, Education and Humanities Research (ASSEHR), Vol. 247. Atlantis Press. (2018).

[11] Mahsun. Dialektologi Diakronis; Sebuah Pengantar. Jogjakarta: UGM Press. (1995).

[12] Suyata, Pujiati. Teori Akomodasi dan Variasi Dialektal dalam Bahasa Jawa Perbatasan Yoghyakarta-Surakarta. littera, volume 3, no. 1, 1. (2004). 